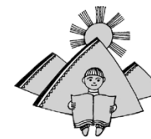

doi: $10.15330 / m s u c .2020 .23 .73-77$

\author{
Марія Черепаня, \\ доктор філософії з педагогічних наук, асистент \\ кафедри педагогіки дошкільної, початкової освіти та \\ освітнього менеджменту, \\ Мукачівський державний університет \\ (м. Мукачево, Україна) \\ Mariia Cherepania, \\ doctor of philosophy in pedagogical sciences, \\ assistant of the department of pedagogy of preschool, \\ primary education and educational management, \\ Mukachevo State University \\ (Mukachevo, Ukraine) \\ mariia.cherepania@gmail.com \\ ORCID ID 0000-0002-2333-5140
}

УДК 37.018.3. 47.7. (09) «1920-1930»

\title{
ПИТАННЯ ТЕОРІЇ ТА МЕТОДИКИ НАВЧАННЯ ТА ВИХОВАННЯ ДІТЕЙ У СПЕЦІАЛІЗОВАНИХ ІНТЕРНАТНИХ ЗАКЛАДАХ ЗАКАРПАТТЯ У 20-30 РP. XX СТОЛІТТЯ
}

Анотація. Мета дослідження - на основі цілісного ретроспективного аналізу вивчити особливості розв'язання питання теорії та методики навчання та виховання дітей у спеціалізованих інтернатних закладах у Закарпатті 20-30рp. XX ст.

Методи дослідження: пошуково-бібліографічний - 3 метою вивчення архівних, бібліотечних каталогів, фондів, описів та бібліографічних видань; контент-аналіз архівних джерел та матеріалів педагогічної періодики - задля виявлення особливостей розв'язання проблеми навчання та виховання дітей у спеціалізованих інтернатних закладах.

У статті здійснено огляд діяльності спеціалізованих інтернатних закладів Підкарпатської Русі 20-30рp. XX ст. у період його перебування в складі Чехословацької республіки. На основі аналізу архівних джерел та педагогічної періодики з'ясовано, що на території тогочасного Закарпаття діти із вадами фізичного, психічного та розумового розвитку здобували освіту в спеціалізованих школах-інтернатах для глухонімих (м. Ужгород), для сліпих (м. Мукачево), для дітей з розумовою відсталістю (м. Великий Севлюш) та інтернаті для калік (м. Мукачево), які входили в структуру Мукачівського державного дитячого будинку. З'ясовано, що представники педагогічної громадськості Закарпаття брали участь у міжнародних конференціях та з'їздах (Братислава, 1930 р., Мукачево, 1922 р., Плзень,1925 р. та ін.), де виступали з доповідями про стан справ у Підкарпатській Русі, ділилися досвідом роботи з дітьми, які потребували особливих умов перебування, навчання та виховання. Про те, що закарпатські педагоги були знайомі й застосовували у своїй роботі європейський досвід організації навчання та виховання дітей з вадами фізичного та розумового розвитку, засвідчують їхні численні публікації на сторінках педагогічного часопису «Учитель» (А. Волошин, М. Добей, В. Довгун, І. Зейкан, С. Куцин, А. Мешко, П. Світлик І. Тимканич, А. Чекан та ін.).

Ключові слова: навчання, виховання, спеціальна освіта, інтернати, спеціалізовані інтернати, Закарпаття.

\section{THE QUESTION OF THEORY AND METHODS OF CHILDREN'S TEACHING AND EDUCATION IN SPECIALIZED BOARDING SCHOOLS OF TRANSCARPATHIA IN 20-30 YEARS OF THE XX CENTURY}

\footnotetext{
Abstract. The study relevance is due to the contradictions between the society requirements to the teachers' professional competence improvement in the boarding education system and incomplete implementation in their preparation the educational innovation and historical and pedagogical experience integration principle, as well as the necessity of institutional establishments activities regional specifics consideration and their organization and activity content insufficient retrospectives peculiarities' study.

Purpose is to study on the holistic retrospective analysis basis the features of solving the theory and teaching and educating children methods in specialized boarding schools in Transcarpathia 20-30 years of the twentieth century.

The methods: search and bibliographic - in order to study archival, library catalogs, collections, descriptions and bibliographic publications; content analysis of archival sources and pedagogical periodicals' materials to identify features of solving the education and upbringing of children's problem in specialized boarding schools.

Results. The article reviews the activities of specialized boarding schools in Subcarpathian Russia in the 20-30s years of the twentieth century, during its involvement in the Czechoslovak Republic. Based on the analysis of archival sources and pedagogical periodicals it was found out that in the territory of the Transcarpathia of those years children with physical, mental and intellectual development disabilities in specialized boarding schools for the deaf and dumb (Uzhgorod), for
} 
the blind (Mukachevo), for children with mental retardation from (Velykyi Sevlyush) and a boarding school for the crippled (Mukachevo), which were part of the structure of the Mukachevo State Orphanage.

It was found out that the Transcarpathians pedagogical community representatives took part in the international conferences and congresses (Bratislava, 1930, Mukachevo, 1922, Pilsen, 1925, etc.), where they made reports on the state of affairs in the Subcarpathian region. Russia, shared their experience of working with children who needed special conditions of staying, education and upbringing. The fact that Transcarpathian teachers were familiar and used in their work the European organizing the education and upbringing of children with physical and mental disabilities experience is evidenced by their numerous publications in the pedagogical magazine "Teacher" (A. Voloshin, M. Dobey, V. Dovgun, I. Zeikan, S. Kutsyn, A. Meshko, P. Svitlyk, I. Tymkanych, A. Chekan, etc.).

Keywords: education, upbringing, special education, boarding schools, specialized boarding schools, Transcarpathia.

\section{ВСТУП}

Постановка проблеми. Актуальність дослідження зумовлюється суперечностями між вимогами суспільства до підвищення професійної компетентності педагогічних працівників у системі інтернатної освіти та неповнотою реалізації в їх підготовці принципу інтеграції освітньої інноватики та історико-педагогічного досвіду, а також необхідністю врахування регіональної специфіки діяльності інституційних установ та недостатнім вивченням ретроспективи особливостей їх організації і змісту діяльності. Проаналізувавши дописи історичних джерел досліджуваного періоду, систематизувавши архівні фонди та матеріали педагогічних видань, слід зазначити, що в період 20-30 рр. XX ст. у Закарпатті простежується зростання інтересу з боку педагогічної громадськості краю до питання теорії та методики навчання та виховання дітей у спеціалізованих інтернатних закладах.

Аналіз наукових досліджень і публікацій. Становлення та розвиток закладів інтернатного типу в історикопедагогічному вимірі вивчали В. Виноградова-Бондаренко, Л. Гребінь, В. Золотоверх, О. Парашевіна, І. Плугатор, В. Покась, Л. Рябкина, Н. Султанова, Т. Янченко та ін. Серед історико-педагогічних досліджень, присвячених становленню та розвитку інтернатної освіти в Закарпатті, виокремлюємо праці А. Машкаринець-Бутко, М. Маринкевича, М. Попадича та ін., проте їхні дослідження інтерпретують розвиток закладів інтернатного типу періоду після 1945 р., коли Закарпаття ввійшло до складу УРСР.

МЕТА І ЗАВДАННЯ ДОСЛІДЖЕННЯ - на основі цілісного ретроспективного аналізу вивчити особливості розв'язання питання теорії та методики навчання та виховання дітей у спеціалізованих інтернатних закладах в Закарпатті 20-30 рр. XX ст.

МЕТОДИ ДОсЛІДЖЕНнЯ: пошуково-бібліографічний - з метою вивчення архівних, бібліотечних каталогів, фондів, описів та бібліографічних видань; контент-аналіз архівних джерел та матеріалів педагогічної періодики - задля виявлення особливостей розв'язання проблеми навчання та виховання дітей у спеціалізованих інтернатних закладах.

\section{РЕЗУЛЬТАТИ ДОСЛІДЖЕННЯ}

У заявлених нами хронологічних межах закарпатська територія належала до Чехословацької республіки у вигляді адміністративно-територіальної одиниці - Підкарпатська Русь з центром у м. Ужгород. Соціальне та освітнє життя краю регламентувалося адміністративними підрозділами Цивільної Управи Підкарпатської Русі - рефератами. Так, 1920 р. з метою соціального захисту населення був створений реферат соціальної опіки, який, зокрема, опікувався й долею дітей-сиріт/дітей, позбавлених батьківського піклування, та дітьми з вадами фізичного або розумового розвитку (Реферат освіти Підкарпатської Русі, арк. 4-5).

Як засвідчують статистичні звіти шкільного інспектора Підкарпатської Русі Йозефа Пешини, упродовж першого десятиліття після завершення подій Першої світової війни істотно зросла кількість дітей, народжених з вадами розумового та фізичного розвитку, які потребували спеціальної освіти. 3 цього приводу Йозеф Пешина зазначав, що «після перевороту понад одна третини дітей шкільного віку не навчалася, ще в 1922/23 році налічувалося дітей, що не навчаються, - 35.835, у 1926/27 р. - таких було 22.210 осіб (через віддаленість до школи понад 4 км 8.533, через нестачу шкіл і вчителів - 8.546, через сліпоту і глухонімоту - 185, через фізичні вади - 987, через велику бідність - 3.464, через душевну слабкість - 495, загалом - 22.210 дітей)» (Реšina, J., 1933, р. 11]. Отже, як бачимо, у 1926-1927 навчальному році із загальної кількості дітей шкільного віку, які не залучені до освітнього процесу, 7,5 \% становлять діти, які мають певні вади у фізичному, розумовому та психічному розвитку. Таким чином, статистичні показники та наявність досвіду діяльності закладів інтернатного типу Австро-Угорського періоду спонукали Чехословацький уряд, а також регіональні освітні управління стимулювати діяльність спеціальних шкіл, які б могли в повному обсязі забезпечити повноцінний розвиток особистості школяра з відхиленнями в розвитку. Відтак з категорії спеціальних шкіл у Підкарпатській Русі, відповідно до архівних даних та звітної документації Й. Пешини, функціонувала школа для глухонімих (м. Ужгород), школа для сліпих (м. Мукачево), інтернат для дітей $з$ розумовою відсталістю (м. Великий Севлюш) та школа для калік (м. Мукачево), які входили в структуру Мукачівського державного дитячого будинку (Учитель, 1927, с. 15).

Особливості організації освітнього процесу, упровадження інноваційних на той час методик навчальної та виховної роботи з дітьми, які перебували в спеціалізованих інтернатних закладах, стали предметом наукових розвідок та педагогічного дослідження закарпатських педагогів, передусім практиків, які працювали з дітьми у вищеназваних закладах. Переважно на сторінках педагогічного часопису «Учитель» вони публікували матеріали, які стосувалися освіти дітей з вадами зору та слуху. Зупинимося на окремих публікаціях. Проблеми освіти дітей з різними патологіями стали предметом дослідження в публікації А. Мешка «О воспитаню глухонімих и о лечебной педагогии взагали» 
(рочник VI (1924), число 1-2), у якій він ділиться спостереженнями за психологічними особливостями глухонімих дітей, їх поведінковими характеристиками, а також особливостями навчання їх спілкування. Публікація призначена для вчителів і вихователів, які працюють з такими дітьми, а також батьків, бо: «се только тот може перечувствовати, кто з ними жиє и в тьсном связь занимаєся з ними» (Учитель, 1924, с. 38). Згодом (1925 р.) А. Мешко опублікує ще одну статтю під цією ж назвою, але зміст її буде значно розширено. У вступі автор дає визначення «лечебної педагогіи», під якою розуміє «воспитанє глухонімих, сліпих, ідіотов т.д.» (Учитель, 1925, с. 245-248). Далі йде опис різновидів глухоти й німоти, описуються психічні характеристики глухонімих дітей, особливості сприймання, їхня соціалізація тощо.

Питання освіти глухонімих дітей розглядалося також Антонієм Чеканом у статті «О розвитку виховання и научованя глухонімих», у якій автор висвітлює історію становлення освіти глухонімих від Стародавньої Греції до початку XX ст. Зокрема, більш докладно зупиняється на методиках навчання грамоти, серед яких виокремлює методику німецького педагога Яна Конрада Аммана, який перший довів, що «и глухонімих дітей можемо образовати так, як нормальних дітей»; а також методику французького педагога Мішеля де Л'Еппе. Різницю в цих двох школах навчання глухонімих А. Чекан пояснював так: «Французька школа стараєся дати глухонімым більш інтелектуальну освіту, опираючися на штучну мімічну мову та писану бесіду. Бесіду артикуловану відкидає, бо освоєня сеї держить задовго», натомість: «Німецька школа же напротив, бере з практичного огляду и подчеркує, що глухонімый $є$ только глухый и, стремиться научити го на бесіду артикуловану и на її основі образовати єго дальше». I, насамкінець, автор зазначає, що виховання і навчання глухонімих дітей є важливим, бо через це «глухонімі не только, що образуються, но и облагороднюються и тым сділаються способными к практичному животу, особливо освоєнем бесіди» (Учитель, 1927 , с.182-185). В іншій статті - «О методах научованя глухонімых» - А. Чекан на основі спостережень під час відрядження до закладу глухонімих у Празі описує особливості застосування різних (французької та німецької) методик навчання дітей, зокрема відзначає прогресивність відродженої Семюлем Гейніком німецької методи (Учитель, 1927, с.20-22).

Питання методики навчання глухонімих дітей розглядається і в статті вчителя письма і читання, математики в школі глухонімих С. Куцина «Справозданя о моій праці при заведєню глухонімых в Ужгороді». Зокрема, автор наводить приклади використання різноманітних вправ для формування в учнів умінь писати, запам'ятовувати написання літер, складів і слів; важливими є вправи на визначення лексичного значення слів, частин мови - іменника та його категорій (рід, число), прикметника, дієслова (Учитель, 1929, с.18-21). У наступній публікації «Научованя глухонімых» автор продовжує наводити приклади вправ, але тут увага акцентується на математичних вправах, які сприяють засвоєнню учнями складу чисел, основних арифметичних дій з ними. Окрім того, автор публікації вказує на необхідність використання в освітньому процесі ритмічних вправ, дитячих ігор, прогулянок. Позитивно впливає на розвиток вихованців моделювання предметів шляхом вирізування з паперу та ліплення з глини. Також у роботі 3 глухонімими учнями вчителям і вихователям варто активно використовувати дихальні та звукові вправи, особливо в поєднані з ритмічними рухами. На думку С. Куцина, педагогові необхідно пам'ятати, що «не робимо з глухонімых дітей щось окремого, але стараємося их принести там, звидки они суть викинуті через свою хвороту. Поводимося з ними так, як з нормальними дітьми и спомагаємо их, щобы так як нормальні діти все виділи і всьо познали» (Учитель, 1929, с.78-82). Автор вищезгаданих публікацій при формуванні системи вправ, які використовуються під час викладання навчальних предметів у школі для глухих, опирається на наукові розвідки європейських учених, а саме: Рудольфа Кратохвіла «Вади речі (Логопедія)», Йосифа Коллара «Навод», а також публікації у фахових часописах Угорщини «Magyar süketnéma oktatás / Освіта глухонімих в Угорщині», «Magyar gyógypedagógia / Лікувальна педагогіка в Угорщині».

3 відкриттям закладу для сліпих дітей актуалізується питання навчання та виховання дітей з вадами зору. 3 першою публікацією щодо специфіки навчання незрячих дітей «Научованя сльпых» виступив Василь Довгун, управитель-учитель закладу для сліпих у м. Мукачеві. У примітці до статті автор написав, що це його власні спостереження із “студійної дороги» (тут: стажування - М.Ч.) до закладу в м. Левоча (Словаччина). Автор акцентує на трьох важливих аспектах у навчанні сліпих дітей: 1) підготовка дітей до навчання (аналізує окремі вправи, які використовуються для розвитку тактильних та слухових відчуттів, наприклад «Скринька всячины», слухання звуків, визначення напряму, сили звуку, густини повітря тощо); 2) зміст навчання (аналізує зміст шкільних предметів, методи і засоби їх вивчення. На запитання «Що і як вчать сліпі?» він відповідає: «Все, що вчать зрячі, але різниться метода, бо на місце зору заступають дотик і слух». Провідна роль, як не парадоксально, належить демонструванню, бо «без нагляду не учиться нич. Что не можна показати у природі, то виробиться з глини. Перше дотикати наглядовати, а потом о них говорити... Учити мало, але добре, часто повторяти ...» тощо); 3) шосте чуття (описує значення інстинкту у сліпих дітей, особливості його розвитку, адже «шестый змысл найліпше розвитый у сліпорожденного») (Учитель, 1924, с. 143-150).

Особливості навчання та виховання незрячих дітей висвітлено також у публікаціях Івана Зейкана та Петра Світлика. Так, у статті І. Зейкана «Пару слов о сліпых» ідеться про типи сліпоти та причини її виникнення. Значну увагу автор приділяє питанню профілактики зору, ролі батьків та учителів у його збереженні, адже боротися із захворюванням органів зору було б успішніше, якби «родители были бы выховани на повинность свою и велику отвичальность, щодо будучого щастя своїх дітей». Віддавати дітей на навчання та виховання у спеціалізовані інтернатні заклади слід якомога швидше - з раннього віку. Як приклад, науковець наводить Чехію і Моравію, де батьки незрячих дітей 
уже з немовлячого віку відвідують педагогів і лікарів для того, щоб діти були максимально підготовлені до навчання в спеціалізованій школі. Відтак, на думку педагога, важливої ролі набуває просвітницька робота з-поміж населення (Учитель, 1927, с.186-188). Після відвідин закладу для сліпих у Мукачеві І. Зейкан пише наступну статтю на тему «Душевный живот сліпых», де визначає головне завдання вчителя-вихователя - у душу дитини посіяти найвищі моральні та естетичні почуття, а також знання, які є необхідними для щоденного використання.

П. Світлик у статті «Выхованя слъпых» розглядає питання історії становлення закладів освіти для сліпих дітей, адже основне завдання школи для сліпих - «подати знаня, насколько оно доступно єму, зробити з него хосенного чоловіка обществу, а найперше хосенного для самого себе» (Учитель, 1927, с.159-160). У наступній публікації «О научаню на письмочитаня сліпих» П. Світлик розглядає особливості навчання дітей читання і письма за допомогою письма Брайля та письма Кляйна. Автор зазначає: «письмо Клайна є важне для сліпця в практичному житю ибо не треба йому просити другого, щобы написав єму письмо, квитанцію или просьбу до уряда, ибо и он самый надрукує так, що и видячі можуть прочитати» (Учитель, 1927, с.228-230). У статті також згадується і про перше у Підкарпатській Русі періодичне видання «Зоря», яке друкувалося спеціальним шрифтом для незрячих.

Питання методики навчання сліпих дітей математики розглядав М. Добей у статті «Численє у школі сліпых» (Учитель, 1929, с.21-22). «Численє в інститутах сліпых єсть право так важно, як в народних школах, - зазначає він. - Метода выучованя є однака, лише що числа не пишуться крейдою, але до того зготовленими значками». Окрім того, автор публікації радить використовувати при навчанні лічби підручні матеріали (пальці, палички, горіхи тощо), а також «веселі задачі», заохочення, змагання як методи підвищення пізнавальної активності учнів. М. Добей вказував і на роль навчання в загальному розвитку особистості дитини з вадами зору, і на його роль у майбутньому дитини в статті «О важности выхованя и образованя сліпых», у якій порівнює сліпу дитину, яка навчається в школі, з дитиною, яка не відвідує школу. На його думку, основне завдання навчання сліпих дітей у школі полягає не тільки в тому, щоб навчити читати, писати, рахувати; найважливішим $€$ те, що дитина «по сконченю школы не мусить дати голову на нещасну жеброту, не мусить опиратися на милосердность людей, но станеся корыстным горожанином державы, а жиє з праці своєї руки» (Учитель, 1929, с. 82-84). Важливим завданням закладу для сліпих є озброїти їх уміннями спілкуватися з оточуючим світом: «як мають сообщатися з видючими, що можуть робити, говорити в товаристві и взагали, як ся мають поводити. Треба их завести в товариство, а дати им вольность, щобы самі познали обставины внешнего світа» (Учитель, 1927, с. 242-244).

Окрім висвітлення досвіду роботи закладів інтернатного типу Закарпаття на сторінках педагогічних журналів, варто окремо зупинитися на участі закарпатських педагогів-вихователів спеціалізованих інтернатних закладів у наукових конференціях та з'їздах з питань організації діяльності інтернатних закладів різних типів. Педагоги та лікарі взяли участь у роботі соціально-лікарського з'їзду в м. Мукачеві, який був проведений 4-7 червня 1922 р. у Резолюції з'їзду зазначалося, що результатом його роботи має бути наповнення педагогічної роботи в дитячих закладах здоров'язбережувальним змістом, зокрема найперше слід дбати про здоров'я дитини від початку їі народження; важливим напрямом у роботі лікарів і вчителів має бути вивчення причин появи у дітей відхилень розвитку; проведення широкої просвітницької і профілактичної роботи з населенням краю; робота над формуванням навичок санітарно-гігієнічної культури в дітей і т. д. Окрім того, з'їздом було ухвалено рішення - розпочати в межах Підкарпатської Русі широкомасштабну протитуберкульозну кампанію, ввести у зміст лікарських курсів факультативну дисципліну «Соціальне лікарство (тут: медицина - М.Ч.)», ввести до штату закладів соціальної опіки лікарів, забезпечити медичні заклади найсучаснішим обладнанням для діагностики та лікування дітей (Реферат освіти Підкарпатської Русі, арк. 2, 5, 7, 10-11).

Представники Підкарпатської Русі взяли участь у роботі ІІ з'їзду фахових учителів шкіл для глухонімих, який відбувся 30 червня - 4 липня 1925 р. у м. Плзень (Чехія). З’їзд мав на меті узагальнити передовий досвід європейських країн у справі навчання та виховання дітей з вадами слуху. У звіті з'їзду зазначено про два напрями його роботи: психолого-педагогічний - соціальна опіка глухонімих і методичний - для фахових учителів шкіл для глухонімих. Цікавим є факт, що на з'їзді з доповіддю виступив фаховий учитель дитячого будинку для глухонімих у м. Ужгород Михайло Грамяк (Реферат освіти Підкарпатської Русі, арк. 167-168).

25-27 жовтня 1930 р. у м. Братислава відбувся IV з'їзд з вивчення дитини, у роботі якого взяли участь і педагоги з Підкарпатської Русі (Ю. Білей, Н. Калинов, О. Копчакова, О. Полянський) (Реферат освіти Підкарпатської Русі, арк. 26). Основна мета роботи з'їзду полягала в обміні науковими дослідженнями та практичними здобутками вчених, які досліджували природу дитини, її лікування, психологію та особливості соціалізації дитини, а також особливості навчання та виховання дітей з вадами фізичного та розумового розвитку. Робота з'їзду полягала в синтезі двох напрямів - медичного та педагогічного, що уможливило всебічно вивчити можливості соціалізації дітей, які перебували в закладах інтернатного типу різних видів.

\section{ВИСНОВКИ ТА ПЕРСПЕКТИВИ ПОДАЛЬШИХ ДОСЛІДЖЕНЬ}

Зважаючи на об'єктивну необхідність розв'язання питання теорії та методики навчання та виховання дітей з вадами фізичного, психічного та розумового розвитку, педагоги Закарпаття у 20-30 рр. XX ст. потребували додаткової освіти, яка б уможливлювала більш ефективно забезпечити освітній процес у спеціалізованих інтернатних закладах. Представники педагогічної громадськості Закарпаття брали участь у міжнародних конференціях та з'їздах (Братислава, 1930 р., Мукачево, 1922 р., Плзень, 1925 р. та ін.), де виступали з доповідями про стан справ у Підкарпатській Русі, ділилися досвідом роботи з дітьми, які потребували особливих 
умов перебування, навчання та виховання. Про те, що закарпатські педагоги були знайомі й застосовували у своїй роботі європейський досвід організації навчання та виховання дітей з вадами фізичного та розумового розвитку, засвідчують їхні численні публікації на сторінках педагогічного часопису «Учитель» (А. Волошин, М. Добей, В. Довгун, І. Зейкан, С. Куцин, А. Мешко, П. Світлик І. Тимканич, А. Чекан та ін.).

Перспективним напрямом подальших розвідок із цієї проблеми може стати актуалізація ретродосвіду в контексті фахової підготовки педагогів за умов упровадження інклюзивного навчання, що зобов'язує вихователів, вчителів і викладачів до набуття професійних компетентностей для організації роботи з цією категорією вихованців, учнів і студентів.

\section{СПИСОК ВИКОРИСТАНИХ ДЖЕРЕЛ}

Реферат освіти Підкарпатської Русі, м. Ужгород, 1925-1926 рр. Звіти вчителів про екскурсію по школах Чехії; звіт про з'їзд учителів шкіл для глухонімих в Брні. ДАЗО. Ф. 28. Оп. 5. Спр. 418. Арк. 1-218.

Реферат освіти Підкарпатської Русі, м. Ужгород, 1930 р. Переписка з шкільними інспекторатами про надання відпуску вчителям для прийняття участі на IV з'їзді вчителів по питанню виховання душевно нерозвинутих дітей. ДАЗО. Ф. 28. Оп. 2. Спр. 1701. Арк. 1-42.

Реферат Соціальної Опіки Підкарпатської Русі, м. Ужгород, 1921 р. Циркуляри Міністерства соціальної опіки і Цивільного Управління по питаннях про подачу урядовцями відомостей в період виїзду урядовців за кордон. ДАЗО. Ф. 37. Оп. 1. Спр. 54. Арк. 1-17.

Реферат Соціальної Опіки Підкарпатської Русі, м. Ужгород, 1922-1923 рр. Резолюції Соціально-лікарського з'їзду в Мукачеві 4-7 червня 1922 р. ДАЗО. Ф. 37. Оп. 1. Спр. 152. Арк. 1-15.

Учитель. Выдає Школьный оддель цивильной управы Подкарпатской Руси. 28 фебруара 1924. Рочник V. 1924. Число. 1-2.

Учитель. Выдає Школьный оддель цивильной управы Подкарпатской Руси. 31 децембра 1925. Рочник VI. 1925. Число. 9-10.

Учитель. Выдає Школьный оддель цивильной управы Подкарпатской Руси. 30 децембра 1926. Рочник VII. 1926. Число. 7-10.

Учитель. Выдає Школьный оддель цивильной управы Подкарпатской Руси. 30 децембра 1927. Рочник VIII. Число. 10.

Учитель. Выдає Школьный оддель цивильной управы Подкарпатской Руси. 28 фебруара 1929. Рочник Х. Число. 1-2.

Учитель. Выдає Школьный оддель цивильной управы Подкарпатской Руси. 30 апрьль 1929. Рочник Х. Число. 3-4.

Учитель. Выдає Школьный оддель цивильной управы Подкарпатской Руси. 31 децембра 1924. Рочник V. 1924. Число. 9-10.

Учитель. Выдає Школьный оддель цивильной управы Подкарпатской Руси. 30 септембра 1927. Рочник VIII. Число. 6-7.

Учитель. Выдає Школьный оддель цивильной управы Подкарпатской Руси. Септембер-октобер 1929. Рочник X. 1929. Число. 7-8.

Учитель. Выдає Школьный оддель цивильной управы Подкарпатской Руси. 30 юнія 1927. Рочник VIII. 1927. Число. 4-5.

Pešina J. Školtvi na Podkarpatské Rusi v pritomnosti. Praha: Statni nakladatelstvo v Praze, 1933. 51 str.

\section{REFERENCES}

Referat osvity Pidkarpatsjkoji Rusi, m. Uzhghorod, 1925-1926 rr. Zvity vchyteliv pro ekskursiju po shkolakh Chekhiji; zvit pro z'jizd uchyteliv shkil dlja ghlukhonimykh v Brni (Teachers' reports on a tour of Czech schools; report on the convention of teachers of schools for the deaf and dumb in Brno). DAZO. F. 28. Op. 5. Spr. 418. Ark. 1-218. (in Ukrainian)

Referat osvity Pidkarpatsjkoji Rusi, m. Uzhghorod, 1930 r. Perepyska z shkiljnymy inspektoratamy pro nadannja vidpusku vchyteljam dlja pryjnjattja uchasti na IV z'jizdi vchyteliv po pytannju vykhovannja dushevno nerozvynutykh ditej (Correspondence with school inspectorates on granting leave to teachers to take part in the IV Congress of Teachers on the issue of education of mentally retarded children). DAZO. F. 28. Op. 2. Spr. 1701. Ark. 1-42. (in Ukrainian)

Referat Socialjnoji Opiky Pidkarpatsjkoji Rusi, m. Uzhghorod, 1921 r. Cyrkuljary Ministerstva socialjnoji opiky i Cyviljnogho Upravlinnja po pytannjakh pro podachu urjadovcjamy vidomostej v period vyjizdu urjadovciv za kordon (Circulars of the Ministry of Social Welfare and the Civil Administration on the submission of information by government officials during the period of departure of government officials abroad). DAZO. F. 37. Op. 1. Spr. 54. Ark. 1-17. (in Ukrainian)

Referat Socialjnoji Opiky Pidkarpatsjkoji Rusi, m. Uzhghorod, 1922-1923 rr. Rezoljuciji Socialjno-likarsjkogho z'jizdu v Mukachevi 4-7 chervnja 1922 r. (Resolutions of the Social and Medical Congress in Mukachevo June 4-7, 1922). DAZO. F. 37. Op. 1. Spr. 152. Ark. 1-15. (in Ukrainian) Uchytelj (Teacher). Vydaje Shkoljnyj oddelj cyvyljnoj upravy Podkarpatskoj Rusy. 28 februara 1924. Rochnyk V. 1924. Chyslo. 1-2. (in Ruthenian) Uchytelj (Teacher). Vydaje Shkoljnyj oddelj cyvyljnoj upravy Podkarpatskoj Rusy. 31 decembra 1925. Rochnyk VI. 1925. Chyslo. 9-10. (in Ruthenian) Uchytelj (Teacher). Vydaje Shkoljnyj oddelj cyvyljnoj upravy Podkarpatskoj Rusy. 30 decembra 1926. Rochnyk VII. Chyslo. 7-10. (in Ruthenian) Uchytelj (Teacher). Vydaje Shkoljnyj oddelj cyvyljnoj upravy Podkarpatskoj Rusy. 30 decembra 1927. Rochnyk VIII. Chyslo. 10. (in Ruthenian) Uchytelj (Teacher). Vydaje Shkoljnyj oddelj cyvyljnoj upravy Podkarpatskoj Rusy. 28 februara 1929. Rochnyk X. Chyslo. 1-2. (in Ruthenian) Uchytelj (Teacher). Vydaje Shkoljnyj oddelj cyvyljnoj upravy Podkarpatskoj Rusy. 30 aprelj 1929. Rochnyk X. Chyslo. 3-4. (in Ruthenian) Uchytelj (Teacher). Vydaje Shkoljnyj oddelj cyvyljnoj upravy Podkarpatskoj Rusy. 31decembra 1924. Rochnyk V. 1924. Chyslo. 9-10. (in Ruthenian) Uchytelj (Teacher). Vydaje Shkoljnyj oddelj cyvyljnoj upravy Podkarpatskoj Rusy. 30 septembra 1927. Rochnyk VIII. Chyslo. 6-7. (in Ruthenian) Uchytelj (Teacher). Vydaje Shkoljnyj oddelj cyvyljnoj upravy Podkarpatskoj Rusy. September-oktober 1929. Rochnyk X. Chyslo.7-8. (in Ruthenian) Uchytelj (Teacher). Vydaje Shkoljnyj oddelj cyvyljnoj upravy Podkarpatskoj Rusy. 30 junija 1927. Rochnyk VIII. 1927. Chyslo. 4-5. (in Ruthenian)

Pešina, J. Školtvi na Podkarpatské Rusi v pritomnosti (Školtvi in Subcarpathian Russia in the present). Praha: Statni nakladatelstvo v Praze, 1933. 51 str. (in Czech) 